\title{
Role of Reflection in Moderating the Relationship between Service-learning and Civic Development
}

\author{
Iqbal Ahmad ${ }^{1}$, Hamdan Said ${ }^{1}$, Syed Shafeq Syed Mansor ${ }^{1}$, Mahani Mokhtar ${ }^{1}$ \& Faizah Abd Ghani ${ }^{1}$ \\ ${ }^{1}$ Faculty of Education, Universiti Teknologi Malaysia, Johor Bahru, Malaysia \\ Correspondence: Hamdan Said, Faculty of Education, Universiti Teknologi Malaysia, Johor Bahru 81310, \\ Malaysia. Tel: 60-7-553-4461. E-mail: p-hamdan@utm.my
}

Received: July 5, 2014 Accepted: July 23, 2014 Online Published: August 15, 2014

doi:10.5539/res.v6n3p74 URL: http://dx.doi.org/10.5539/res.v6n3p74

\begin{abstract}
This study examined the correlation between service-learning and civic development and its three dimensions: civic knowledge, civic skills and civic commitment. Service-learning is a unique experiential teaching and learning methodology that promotes civic learning of students by connecting academic learning with community service. The study also assessed the moderating effect of reflection on the relationship of service-learning with civic development. Using a correlation design, this study surveyed 250 teachers in three public universities in Malakand Division, Pakistan. Results of the study showed a significant positive correlation between service-learning and civic development. The study also showed that reflection significantly moderates the relationship between service-learning and civic development.
\end{abstract}

Keywords: service-learning, reflection, civic development, civic knowledge, civic skills, civic commitment

\section{Introduction}

There is a close relationship between education and civic development. The students who participate in service-learning develop essential civic skills such as effective communication, leadership and teamwork (Said et al., 2014). The basic aim of education is to prepare active and participative citizens for the society (Steinberg, Bringle, \& Williams, 2010). One of the roles of educational institutions is to adequately equip students with knowledge and skills for enabling them to learn and practice good citizenship (Giles \& Eyler, 1994; Konukman \& Schneider, 2012). Developing civic responsibility in the students allows the schools to fulfill their basic mission which is the preparation of good citizens. To achieve this purpose, schools adopt various approaches and technologies to develop such individuals. However, one such effective pedagogy that has currently attracted the attention of researchers and academicians is service-learning. This teaching method has been accepted as a popular educational approach over the last three decades. According to Strage (2000), service-learning is a teaching methodology that derives its theoretical foundations from David Kolb and Dewey's theory of experiential education. According to these theorists, experience provides the foundation for learning.

Dewey believed that children should learn through experience and for this purpose, he suggested realistic tasks and authentic experiences to be structured and designed as learning goals. He further believed that in this way students will actively learn, grow socially that illuminates their latent talents (Steinberg, Hatcher, \& Bringle, 2011). Service-learning is conducted in the community sites as against the traditional classroom teaching. This approach in teaching and learning provides more practical opportunities to students that effectively refine their latent talents. This exposes the reciprocal nature of service-learning where both the server and the served receive equal gains (Simons \& Cleary, 2006). Experiential learning and service to the community have been together since time immemorial. But their true relationship was exposed in 1967 when two famous educators such as Sigmon and Ramsay, for the first time, coined the term Service-Learning. Later on, service-learning was incorporated in the curriculum of many educational institutions in the world in 1970s which revolutionized the field of education (Chickering, 2001; Bringle \& Hatcher, 1996).

Literature has indicated that the civic mission of educational institutions is traced back to the classical period. According to Aristotle, the aim of education is development of useful citizen. This reveals that the aim of education is not only to prepare for productive careers. Rather, it also aims to enable students to live lives of dignity and purpose (Said et al., 2014). Education not only aims to provide new knowledge to students, rather developing the skills of students in such a manner that they are able to channelize the knowledge in real life 
situations (Astin, Sax, \& Avalos, 1999). These writers also believed that during the service practice students should also realize their responsibilities toward their fellow citizens and society.

Classroom and service activities that include such discussions and learning opportunities can help students hone their skills that are vital to function as active members of a democratic society and to grapple with the challenges of the new century effectively (Adler-Kassner, Crooks, \& Watters, 1997). Service-learning is an instructional methodology that connects academic course preparation with service in the community. This exposure of students in the wider community enables the students to learn and serve at the same time (Stukas, Clary, \& Snyder, 1999). The students further have wider interactions with different people in the community and gain first-hand knowledge of the issues and their solution (Giles \& Eyler, 1994; Valerius \& Hamilton, 2001; Pompa, 2002). Studies have indicated that to enhance academic success, educators use variety of teaching and learning methods. One such method is service-learning. Service-learning is a teaching and learning instrument that infuses academic goals with community service enriching learning, developing civic responsibility and fostering positive interaction between community and students in order to promote learning process (Miller, 1997; Michael, 2005). Although, the roots of service-learning as an experiential learning approach go back to the educational theories of progressivism of John Dewey, experiential learning theory of Kolb and social learning theory of Bandura, it formally began to develop in the 1960s and early 1970s. On top of that, it became a popular teaching and learning strategy in 1990s in England and in America in 1993 when National and Community Service Act were passed (Michael, 2005; Limieux \& Allen, 2007; Felten \& Clayton, 2011).

Literature reveals that in the present day service-learning continues to maintain its unique position as an active instructional method. Studies further indicate that service-learning has positive effects on educational development of students in all disciplines of education. The theory of service-learning mainly draws its inspiration from the model of experiential learning presented by Kolb (Park, 2002). According to Kolb model, learning occurs in four stages. For example, in the process of experience, some choose concrete experience. Others tend to prefer abstract rationalization such as thinking, planning and analyzing. Some prefer reflection in which the students sit back and revisit the quality of their performance which enables them to see aspects of success and failure in a performance. Kolb model clearly contains a situation where the learners interact with the environment actively. In this way experiential learning occurs which contains reflection, action, and experience. Service-learning also creates a learning environment where learners apply their skills and knowledge to do something meaningful. The domains of educational learning include a wide range of skills, attitudes, and behaviors which are necessarily to be developed in students as part of the civic development (Eyler \& Giles, 1997; Moore, 2000; Griffith, 2012).

Over the last one decade, it has been observed that educational institutions in the developed world generally and in the developing world particularly do not seriously consider these essential skills and attitudes in their educational endeavors (Strage, 2000). But in the latter half of the $20^{\text {th }}$ century, the revolution in the democratization of schools has changed the whole world dramatically (Croddy, 2000). In current times, students are expected to learn more sophisticated skills, updated knowledge and inclusive behaviors to co-exist in a more plural world characterized by civic values that defines the norms and standards of life for the people. In more recent years, a sudden increase has been seen in the practices of service-learning all over the world. Educationists and researchers strongly believe that it is a useful theory which has the capacity to answer many questions related to citizenship and democracy (Furco, 2007; Conrad \& Hedin, 1982).

Despite dramatic popularity of service-learning as effective teaching and learning pedagogy and its overwhelming practice in educational institutions around the world, it is observed that there are some methodological problems associated with the research on service-learning (Michael, 2005). Most of the previous studies have directly examined the relationship of service-learning with civic development. Very few studies have assessed the role of reflection on the outcomes of service-learning. These studies have not directly measured the moderating effect of reflection between civic development and service-learning (Keilly, 2005). Hence, this study expanded the current literature on service-learning by using reflection as a moderator. The framework shows the relationship between the three main variables such as service-learning, civic education and reflection. It is a new model which was developed after a thorough review of the literature.

\section{Research Framework and Justification}

On the basis of literature review the following research model was developed for this study. Although many studies on the same model have been conducted around the world, but most of these studies have been done in the developed world. Fewer studies have been done in the developing world and no study has so far been done in Pakistan. This study will contribute towards the literature of service-learning and civic development by using the 
above model in new context. The study could provide new insights for future researchers and practitioners of service-learning.

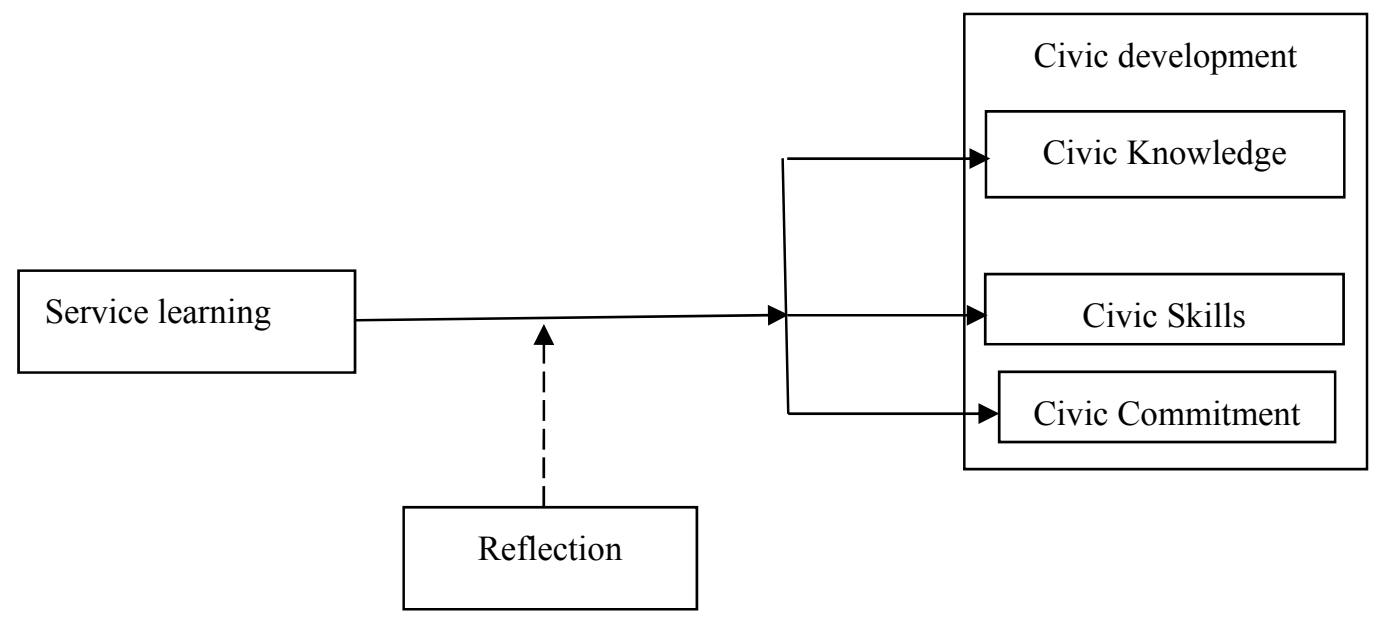

Figure 1. Research Framework

\subsection{Research Objectives}

- To investigate the relationship of service-learning with civic development.

- To examine the relationship of service-learning with civic knowledge, civic skills and civic commitment.

- To assess the moderating effect of reflection on the relationship between service-learning and civic development and its three dimensions.

\subsection{Research Questions}

- What is the relationship of service-learning with civic development?

- What is the relationship of service-learning with civic knowledge, civic skills and civic commitment?

- Does reflection moderate the relationship between service-learning and civic development and its three dimensions?

\subsection{Research Hypotheses}

$\mathbf{H}_{1}$ : There is a positive relationship between service-leaning and civic knowledge.

$\mathbf{H}_{2}$ : There is a positive relationship between service-learning and civic skills.

$\mathbf{H}_{3}$. There is a positive relationship between service-learning and civic commitment.

$\mathbf{H}_{4}$ : Reflection moderates the relationship between service-learning and civic development and its three dimensions such as civic knowledge, civic skills and civic commitment.

\section{Methodology}

\subsection{Population and Sampling}

Using a correlation design, this study surveyed 250 university teachers' attitudes from three public universities in Malakand division, Pakistan. The total population of the study was 700. The sampling was done using Krejcie and Morgan (1970) formula of sampling. The sample was selected on the basis of random sampling technique. Random sampling technique ensures the equal representation of all respondents and helps in better generalization (Gay, Mills, \& Airasian, (2009).

\subsection{Measures}

To measure the relationship between the above mentioned variables three different scales were used. To measure the moderating effect of reflection on the relationship between service-learning and civic development, a scale developed by Lambight and $\mathrm{Lu}$ (2009) was used. To measure civic development and its three dimensions such as civic knowledge, civic skills and civic commitment a scale named Student Service-Learning Course Survey (SSLCS) was used. This scale was originally developed and used by Eyler and Giles (1999) in their earlier 
studies. Another scale, Civic Attitude Skill Questionnaire (CASQ) was used to collect data on students' civic development. This scale was originally developed and used by developed by Moely et al. (2002). The alpha reliability of all the scales was above .80. This allowed the researcher to collect data confidently and comfortably.

\section{Results}

The purpose of this study was to examine the relationship between service-learning and three dimensions of civic development. The study also aimed to measure the moderating effect of reflection on the relationship between service-learning and civic development and its three dimensions such as knowledge, skills and commitment.

\subsection{Correlation Analysis}

Correlation analysis was conducted to examine the relationship between independent variable (service-learning) and the dependent variables (civic knowledge, civic skills, civic commitment).

Table 1. Correlation analysis of service-learning with civic development and its dimensions

\begin{tabular}{lcccc}
\hline Variables & Civic knowledge & Civic skills & Civic Commitment & Service learning \\
\hline Civic knowledge & 1 & & & \\
Civic skills & $0.783^{*}$ & 1 & 1 & 1 \\
Civic commitment & $0.67^{*}$ & $0.741^{*}$ & $0.72^{*}$ & 1 \\
Service learning & $0.574^{*}$ & $0.69^{*}$ & & \\
\hline
\end{tabular}

*Correlation is significant at the 0.01 level (2-tailed).

Table 1 indicates the relationship between the independent variable and dependent variable shown at $p$ value of 0.01. This shows that service-learning is positively correlated with civic development and its three dimensions such as civic knowledge, civic skills and civic commitment.

\subsection{Regression Analysis}

Regression analysis was used to test the research hypotheses. The results for each variable are discussed below.

Hypothesis 1: There is positive relationship between Service-learning and civic knowledge

Table 2. Correlation of service-learning with civic knowledge

\begin{tabular}{lccccc}
\hline Variables & R square & t-value & Coefficient & F-value & P value \\
\hline Service-learning & 0.612 & 14.33 & 0.71 & 269.0 & 0.00 \\
\hline
\end{tabular}

Table 2 shows the value of coefficient beta is calculated as 0.71 which shows a significant correlation between the variables. The value of R-square is calculated as $(0.612)$ which shows that $(61.2 \%)$ variation in the dependent variable (civic knowledge) is explained by independent variable (service learning). The model's goodness of fit is shown by $\mathrm{F}$-value that is 269.0 . Hence, $\mathrm{H}_{1}$ was accepted that service-learning is a positive correlation with civic knowledge.

Hypothesis 2: There is a positive relationship between service learning and civic skills

Table 3. Correlation between service-learning and civic skills

\begin{tabular}{lccccc}
\hline Variables & R square & t-value & Coefficient & F-value & P value \\
\hline Service learning & 0.641 & 17.33 & 0.67 & 274.1 & 0.00 \\
\hline
\end{tabular}

Table 3 shows the value of coefficient Beta is measured as 0.67 which shows that there is a significant relationship between the variables. The value of $\mathrm{R}$-square is calculated as 0.641 which shows that $64.1 \%$ variation in the dependent variable (civic skill) is explained by independent variable (service-learning). The model's goodness of fit is shown by F-value that is 274.1. Therefore $\mathrm{H}_{2}$ is accepted that service-learning has a positive correlation with civic skill. 
Hypothesis 3: There is a positive relationship between service-learning and civic commitment

Table 4: Correlation of service-learning with civic commitment

\begin{tabular}{cccccc}
\hline Variables & R square & t-value & Coefficient & F-value & P value \\
\hline Service learning & 0.682 & 16.31 & 0.78 & 288.0 & 0.00 \\
\hline
\end{tabular}

Table 4 shows the value of co-efficient beta is calculated as 0.78 which show a significant relationship between the variables. The value of R-square is 0.682 which show $68.2 \%$ variation in the dependent variable (civic commitment) is explained by independent variable (service-learning). The model's goodness of fit is shown by F-value that is 288.00 . Therefore, $\mathrm{H}_{3}$ is accepted that service-learning has a positive correlation with civic commitment.

\subsection{Descriptive Analysis}

The correlation analysis and descriptive statistics for the three variables is presented below. The correlation coefficients values are less than 0.90 which show that the data is not affected by serious co-linearity problem.

Hypothesis 4: Reflection moderates the relationship between service-learning and civic development

Table 5. Reflection moderates the relationship between service-learning and civic development

\begin{tabular}{lccccccc}
\hline No & Variables & N & Maximum & Minimum & Mean & Standard Deviation & Variance \\
\hline 1 & Service-Learning & 250 & 4.34 & 2.29 & 3.5 & 0.458 & 0.210 \\
2 & Reflection & 250 & 4.67 & 1.83 & 3.4 & 0.626 & 0.393 \\
3 & Civic development & 250 & 4.67 & 3.02 & 3.6 & 0.545 & 0.60 \\
\hline
\end{tabular}

Table 5 shows that the interaction of reflection is significantly associated with service-learning and civic development. To test the moderating effect of reflection on the relationship between service-learning and the civic development, we first created interaction terms by multiplying classroom assessment with reflection. The tables show that reflection moderates the relationship between service-learning and civic development.

\section{Discussion}

This study examined the relationship between service-learning and civic development and its three dimensions such as civic knowledge, civic skills and civic commitment. The study also assessed the moderating effect of reflection on the relationship between service-learning and civic development and its three dimensions.

The results of the study revealed that there was a highly positive correlation between service-learning and civic development and all its three dimensions such as civic knowledge, civic skills and civic commitment. The study also demonstrated that reflection significantly moderates the relationship between service-learning and civic development as well as its three dimensions as mentioned above. On the basis of this study it is easy to predict that civic knowledge, skills and commitment of students could be enhanced by meaningfully engaging them in service-learning activities.

Furthermore, the results of this study also supported the results of the earlier studies that service-learning positively affects civic development of students (Giles \& Eyler, 1994; Bringle \& Hatcher, 1996; Strage, 2000; Simons \& Cleary, 2006; Steinberg, Bringle, \& Williams, 2010; Steinberg, Hatcher, \& Bringle, 2011). The results of the study added to the literature on service-learning from a different contextual perspective by using a new model and testing it in a developing country context.

\section{Conclusions}

The study concludes that there is a significant relationship between service-learning and civic development as well as civic knowledge, civic skills and civic commitment. Additionally, the study also found that reflection significantly moderates the relationship between service-learning and civic development and its three dimensions. The results of this study confirmed the findings of the previous studies. The results of this study have strong implications for teachers, students and communities as this study strongly supports that service-learning is a unique and useful teaching and learning pedagogy that can be effectively used to develop civic knowledge, civic skills and civic commitment of among students. The study also provides a clear indication for the educationists 
and policy makers in Pakistan for prioritizing service-learning as an educational strategy to achieve the aims of civic education in the country

\section{Future Research}

This study examined the relationship between service-learning, civic development and its three dimensions. However, it is suggested that future research should focus on the other remaining dimensions such as leadership skills, communication skills, teamwork skills, problem-solving skills and so on. This study was conducted only in three universities with a limited sample size. It is suggested that future research should select more sample size. This would effectively ensure the reliability and generalization of the results.

\section{References}

Adler-Kassner, L., Crooks, R., \& Watters, A. (1997). Writing the community. Concepts and models for service-learning in composition. Washington, DC: American Association for Higher Education.

Astin, A. W., Sax, L. J., \& Avalos, J. (1999). Long-term effects of volunteerism during the undergraduate years. Review of Higher Education, 22(2), 187-202.

Bringle, R., \& Hatcher, J. (1996). Implementing service-learning in higher education. The Journal of Higher Education, 67(2), 221-231. http://dx.doi.org/10.2307/2943981

Chickering, A. L. (2001). Maximizing civic learning and social responsibility. Boston, Massachusetts: New England Resource Center for Higher Education.

Conrad, D., \& Hedin, D. (1982). The impact of experiential education on adolescent development. Child \& Youth Services, 4(3/4), 57-76. http://dx.doi.org/10.1300/J024v04n03_08

Croddy, M. (2000). Fostering civic responsibilities. Constitutional Rights Foundation: Service Learning Network, $8(1), 1-15$.

Eyler, J., \& Giles D. (1999). Where's the learning in service-learning? San Francisco: Jossey \& Bass.

Felten, P., \& Clayton, P. (2011). Service-learning. New Directions for Teaching and Learning, 128, 75-84. http://dx.doi.org/10.1002/tl.470

Furco, A. (2007). Advancing youth academic success, school engagement, and international leadership through service-learning. MN: National Youth Leadership Council.

Gay, L. R., Mills, G. E., \& Airasian, P. (2009). Educational research: Competencies for analysis and applications (9th ed.). Upper Saddle River, NJ: Pearson

Giles, D., \& Eyler, J. (1994). The impact of a college community service laboratory on students', personal, social and cognitive outcomes. Journal of Adolescence, 17, 327-339. http://dx.doi.org/10.1006/jado.1994.1030

Grifith, J. (2012). A decade of helping: Community service among recent high school graduates attending college. Nonprofit and Voluntary Sector Quarterly, 41(5) 786-801. http://dx.doi.org/10.1177 /0899764011417720

Hatcher, J. A., \& Bringle, R. G. (1997). Reflection: Bridging the gap between service and learning. College Teaching, 45(4), 153-158. http://dx.doi.org/10.1080/87567559709596221

Keilly, R. (2005). A transformative learning model for service-learning: A longitudinal case study. Michigan Journal of Community Service Learning, 12(1), 5-22.

Konukman, F., \& Schneider, R. C. (2012) Academic service learning in PETE: Service for the community in the $21^{\text {st }}$ century. Strategies: A Journal for Physical and Sport Educators, 25(7), 15-18.

Krijcie, R. V. \& Morgan, D. W. (1970). Determining sample size for research activities. Educational and Psychological Measurement, 30, 607-610.

Lambright, K. T., \& Lu, Y. (2009). What impacts the learning in service learning? An examination of project structure and student characteristics. Journal of Public Affairs Education, 15(4), 425-444.

Limieux, C. M., \& Allen, P. D. (2007). Service learning in social work education: The state of knowledge, pedagogical practicalities, and practice conundrums. Journal of Social Work Education, 43(2), 309-325. http://dx.doi.org/10.5175/JSWE.2007.200500548

Michael, R. L. (2005). Service learning improves college performance. Academic Exchange Quarterly, 9(1), 110-114. 
Miller, J. (1997). The impact of service-learning experiences on students' sense of power. Michigan Journal of Community Service Learning, 4(1), 16-21.

Moely, B. E., Mercer, S. H., Ilustre, D., Miron, D., \& McFarland, M. (2002). Psychometric properties and correlates of the civic attitudes and skills questionnaire (CASQ): A measure of students' attitudes related to service learning. Michigan Journal of Community Service Learning, 8(2), 15-26.

Moore, D. T. (2000). The relationship between experiential learning research and service-learning research. Michigan Journal of Community Service Learning, Special Issue 1, 124-128.

Park, B. C. B. (2002). A teaching note on service-learning through applied community research. Academic Exchange Quarterly, 6(3), 62-65.

Pompa, L. (2002). Service-learning as crucible: Reflections on immersion, context, power, and transformation. Michigan Journal of Community Service Learning, 9(1), 67-76.

Said, H., Ahmad, I., Yasin, M., Syed Mansor, S. S., Hassan, Z., \& Alrubaay, I. (2014). Using e-service learning for promoting digital citizenship. Life Science Journal, 11(3), 154-159.

Simons, L., \& Cleary, B. (2006). The influence of service-learning on students' personal and social development. College Teaching, 54(4), 307-319. http://dx.doi.org/10.3200/CTCH.54.4.307-319

Steinberg, K. S., Bringle, R. G., \& Williams, M. J. (2010). Service-learning research primer. Scotts Valley, CA: National Service-Learning Clearinghouse.

Steinberg. K. S., Hatcher, J. A., \& Bringle, R. G. (2011). Civic-minded graduate: A north star. Michigan Journal of Community Service Learning, 18(1), 19-33.

Strage, A. A. (2000). Service-learning: Enhancing student learning outcomes in a college-level course. Michigan Journal of Community Service Learning, 7(1), 5-13.

Stukas, A. A., Jr., Clary, E. G., \& Snyder, M. (1999). Service-learning: Who benefits and why. Social Policy Report Society for Research in Child Development, 13(4), 1-20.

Valerius, L., \& Hamilton, M. (2001). The community classroom: Serving to learn and learning to serve. College Student Journal, 35(3), 339-344.

\section{Copyrights}

Copyright for this article is retained by the author(s), with first publication rights granted to the journal.

This is an open-access article distributed under the terms and conditions of the Creative Commons Attribution license (http://creativecommons.org/licenses/by/3.0/). 